This item was submitted to Loughborough's Research Repository by the author.

Items in Figshare are protected by copyright, with all rights reserved, unless otherwise indicated.

\title{
Integrating counter-terrorist resilience into sustainability
}

PLEASE CITE THE PUBLISHED VERSION

http://www.urbandesignandplanning.com

\section{PUBLISHER}

(c) Institution of Civil Engineers

\section{VERSION}

VoR (Version of Record)

\section{LICENCE}

CC BY-NC-ND 4.0

\section{REPOSITORY RECORD}

Coaffee, Jon, and Lee S. Bosher. 2019. "Integrating Counter-terrorist Resilience into Sustainability". figshare. https://hdl.handle.net/2134/9203. 
This item was submitted to Loughborough's Institutional Repository (https://dspace.lboro.ac.uk/) by the author and is made available under the following Creative Commons Licence conditions.

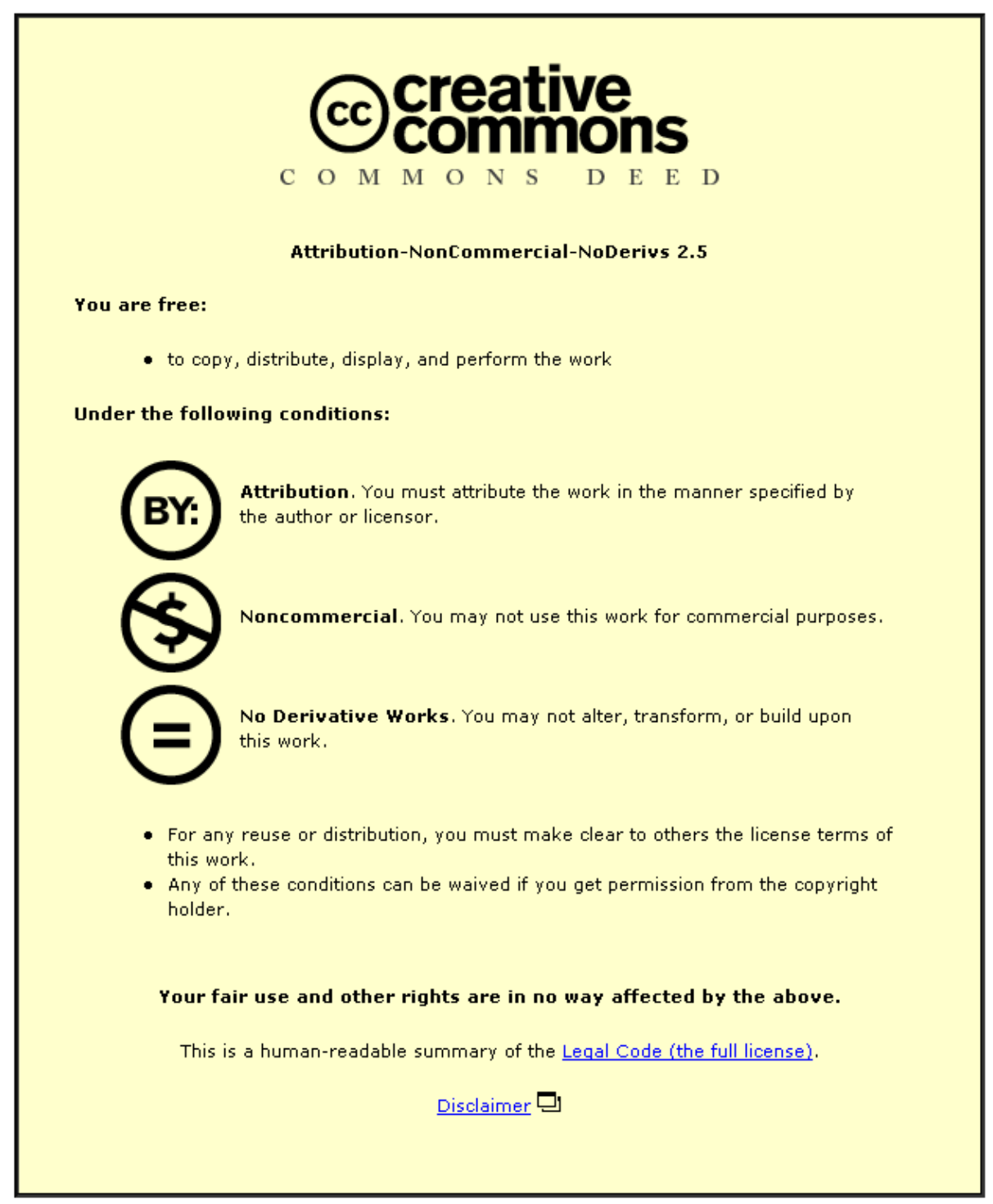

For the full text of this licence, please go to: http://creativecommons.org/licenses/by-nc-nd/2.5/ 

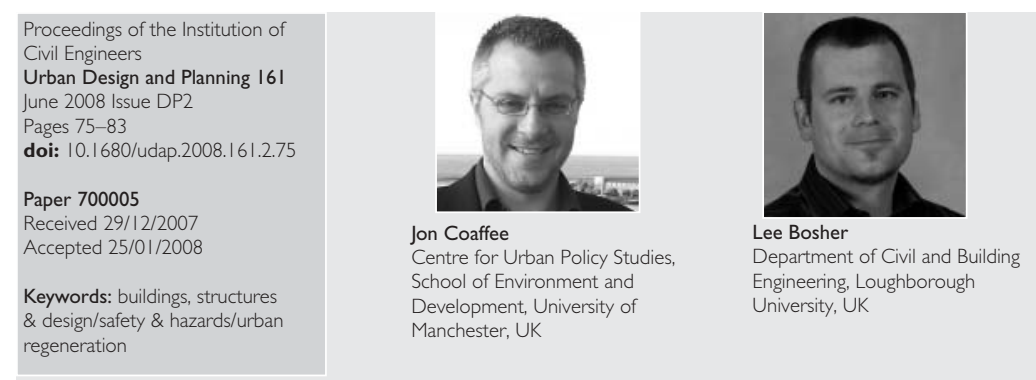

\section{Integrating counter-terrorist resilience into sustainability}

\section{J. Coaffee PhD and L. Bosher PhD, FRGS, FICDDS}

In recent years ideas of resilience have been increasingly embedded within urban planning and design practice as attempts have been made to make the built environment and critical infrastructure more resistant to external risk from natural hazards, particularly those associated with climate change, or from new security challenges facing many cities as a result of the ongoing threat of terrorism. The rapid renaissance of central urban areas in the last decade has given ample opportunities to apply such resilient principles to the construction of new buildings or regeneration areas, facilitated by changes in building regulations and the planning system concerned with broader issues of safety and sustainability. This paper argues that the embedding of resilience into the planning, design and engineering of the built environment is about not only security and community safety concerns but also the environmental benefits that might be achieved by integrating secure and sustainable design. The authors also argue that to date there has been limited integration of security and sustainability construction principles but that significant opportunities exist in the future for such sustainable urbanism to be commonplace.

\section{INTRODUCTION: TOWARDS A RESILIENT CITY}

In recent years metaphors of 'resilience' have been used to describe how cities are attempting to embed security and risk management features into the built environment. Resilience is understood as, "the ability of social units (e.g. organizations, communities) to mitigate hazards, contain the effects of disasters when they occur, and carry out recovery activities in ways that minimise social disruption and mitigate the effects of future disasters'. ${ }^{1}$ This increased focus on resilience is seen as part of a broader drive towards more 'safe' and sustainable communities and in particular is connected to concerns about environmental sustainability. The protection of the built environment has received widespread attention as a result of concerns over the impact of natural hazards ${ }^{2-4}$ or a large-scale terrorist attack $^{5}$ on the functioning of large urban areas. Recent initiatives to protect the built environment have focused on the capability of the built environment to both resist and recover rapidly following disastrous events. Dainty and Bosher, however, have suggested that the nature of the interaction in the UK between those who plan, design, construct, operate and maintain the built environment provides a problematic context within which to integrate urban resilience. ${ }^{6}$ The socio-political landscape of the construction industry and associated professions, plus the speed and profit motives of many urban regenerators ${ }^{7}$ arguably act as fundamental impediments to the achievability of this goal. Attaining urban resilience will therefore demand a paradigm shift in the way that built environment professionals integrate their activities and interact with the communities within which built assets reside. ${ }^{6}$ As David Godschalk argues, 'If we are to take the achievement of urban resilience seriously, we need to build the goal of the resilient city into the everyday practice of city planners, engineers, architects, emergency managers, developers and other urban professionals'. ${ }^{8}$

Recent years have witnessed a shift to a more transdisciplinary concept of resilience that integrates the physical (both built and natural) and socio-political aspects of resilience. This change has been crucial because the socio-political and managerial aspects are arguably as important to the attainment of resilience as the physical aspects; resilient engineering also demands a more resilient infrastructural context with regard to the professions and the structures and processes which govern construction activity. ${ }^{6}$ Therefore, 'a resilient built environment should be designed, located, built, operated and maintained in a way that maximises the ability of built assets, associated support systems (physical and institutional) and the people that reside or work within the built assets, to withstand, recover from, and mitigate for the impacts of extreme natural and human-induced hazards'. ${ }^{6}$

In short, how can cities be made more 'resilient' particularly in the context of sustainable urban regeneration initiatives? The present authors argue in this paper that this requires not just engineering solutions to 'harden' buildings from potential attack, but also systems of governance that seek a co-ordinated effort among built environment professionals. As Richard Little has noted, resilience is not just about physical robustness or designing out risk, and that a fully inclusive governance system be enacted for dealing with resilience.

Developing a successful strategy for urban security requires that these interactions be understood and enabled by all involved stakeholders. Security will be neither holistic nor effective if it is restricted to narrow professional or disciplinary stovepipes or if interactions among government officials, security professionals, program and financial staff, and emergency responders occurs only on a product-by-product basis. ${ }^{9}$ 
Importantly, this push to incorporate resilient principles into systems of planning and design has been undertaken in many cities within a context of widespread urban revitalisation, renewal and regeneration, particularly in the central areas of cities. This 'design-led' approach, commonly referred to in the UK as 'urban renaissance' and in North America and beyond as 'new urbanism', has stimulated an array of new commercial and residential buildings, often making extended use of glass (perhaps the greatest cause of injury in bomb blasts is caused by glass fragments), and has been focused upon improving the liveability of urban areas by promoting the greater use of public spaces, greater access to the public realm more generally, and the ongoing 'beautification' of many central city areas. ${ }^{10}$ Alongside a new-look urban design has come the opportunity (and in many cases the necessity) to integrate an array of security features in the design and maintenance of the city in response to the occurrence of and fear of crime and terrorism. ${ }^{11}$ Equally, given global concerns of climate change, issues of environmental sustainability have also begun to be seriously considered within the construction of the built environment ${ }^{12}$ and planning for climate change is now a key concern within urban design, architecture and planning professions. ${ }^{13}$

These issues raise a key question: how can built environment professionals balance the requirements of counter-terrorism with environmental sustainability within regeneration schemes? The remainder of this paper is divided into two parts. First, the enhanced requirements and implications of safety and security (so-called safe growth) within the regenerating built environment are highlighted. Second, attempts to integrate such security concerns with ideas of environmental sustainability are discussed.

\section{TARGET HARDENING AND SECURE DESIGN}

The embedding of so-called 'safe growth' principles is now a key concern within the construction of the built environment. The 'safe growth' movement-which has developed in recent years in America as a reaction to natural hazards and the increased risk of terrorist attack-is a set of principles by which urban planners in particular, and built environment professionals more generally, can consider multiple types of risk, including crime, terrorism and natural hazards, in planned or existing developments. ${ }^{14}$ For example, the American Planning Association highlights that "planners and policy makers must consider the sources of risk, such as geologic or weather-related natural hazards, technological hazards that generate pollution or poisons, terror, error, crime, and economic'. ${ }^{15}$

In short, 'safe growth' uses planning to increase community safety through encouraging the building of resilience in design and management systems. It also aims to facilitate a joined-up approach to development among emergency planners, spatial planners and other built environment professionals through incorporating risk management into built environment decision-making. ${ }^{16}$

In the UK such guidance on the links between safety and security and design, planning and regeneration have traditionally come through publications such as Safer Places: The Planning System and Crime Prevention ${ }^{17}$ and more localised supplementary guidance for 'designing out crime' or the adoption of 'secure by design' principles. More recently, and given the increased threat from terrorism to the urban environment, some countries are now beginning to consider how built environment professionals might assist in designing out, or reducing the impact of, terrorism. This has meant that in some contexts security professionals and planners are beginning to work side by side in an attempt to design-in crime reduction and counter-terrorist security features to new developments or existing urban spaces deemed a potential target of attack.

This focus on embedding safety and security features into the urban realm as a response to terrorism is not unprecedented. Going back as far as the early 1970s in Northern Ireland, brutal target hardening against an array of likely targets such as police stations and army barracks was seen, as well as the sealing off of commercial districts in a number of towns by a combination of concrete blocks and razor wire and, in the case of Belfast city centre, a ring of tall steel gates (the so-called ring of steel) to stop vehicle access. ${ }^{18}$ More recently, in Manchester after the 1996 bomb attack by the Provisional IRA, which devastated a large part of the city centre, a commitment to embed security features into the new regeneration master-plans to improve the resilience of the city have been vital for boosting the attractiveness of the city centre as a safe and secure commercial and residential environment, and a high-profile events venue. ${ }^{19}$ Such measures embedded within the design of the new remodelled city centre over recent years include a vehicle access system that bars non-bus traffic from the city centre by a series of retractable steel bollards (Fig. 1), bomb-proof litter bins (Fig. 2) and a state-of-the-art centralised closed-circuit television (CCTV) scheme (Fig. 3). ${ }^{20}$

Such counter-terror design solutions do, more often than not, take a technical determinist approach, which means that 'fortress-like' environments with an emphasis on territorial security are encouraged or seen as 'the way to go'. This now often involves advice being given about the target hardened properties of building structures (blast-proof glass and nonfragmentary materials), 'toughened' barriers to create checkpoints at access and egress points to a facility, or the creation of a suitable stand-off area between a public road and a building. Highlighting the tactics that might be utilised to counter the impacts of terrorism David Hadden, security consultant at Arup, has identified a number of the key principles that should be considered early in the planning and design process. ${ }^{21}$

(a) Deflect an attack by showing through layout, security and defences that the chance of success for the terrorist is small. Targets that are likely to be attractive to terrorists should be made anonymous where possible.

(b) Disguise the valuable parts of a potential target, so that the energy of attack is wasted on the wrong area and the attack, although completed, fails to make the impact that the terrorist seeks but is reduced to an acceptable annoyance.

(c) Disperse a potential target, so that an attack could never involve a large enough area to cause significant 

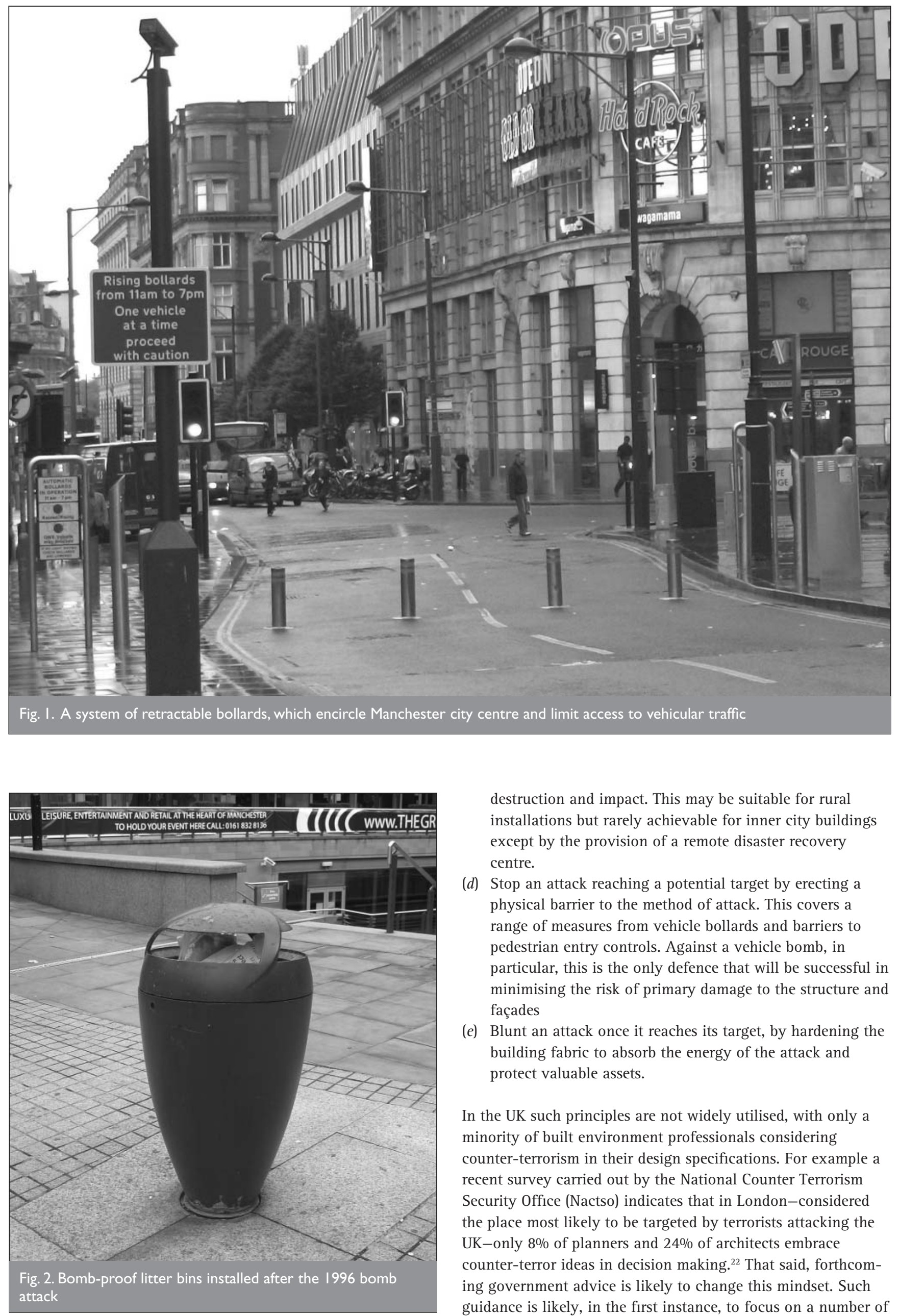

destruction and impact. This may be suitable for rural installations but rarely achievable for inner city buildings except by the provision of a remote disaster recovery centre.

(d) Stop an attack reaching a potential target by erecting a physical barrier to the method of attack. This covers a range of measures from vehicle bollards and barriers to pedestrian entry controls. Against a vehicle bomb, in particular, this is the only defence that will be successful in minimising the risk of primary damage to the structure and façades

(e) Blunt an attack once it reaches its target, by hardening the building fabric to absorb the energy of the attack and protect valuable assets.

In the UK such principles are not widely utilised, with only a minority of built environment professionals considering counter-terrorism in their design specifications. For example a recent survey carried out by the National Counter Terrorism Security Office (Nactso) indicates that in London-considered the place most likely to be targeted by terrorists attacking the UK-only $8 \%$ of planners and 24\% of architects embrace counter-terror ideas in decision making. ${ }^{22}$ That said, forthcoming government advice is likely to change this mindset. Such guidance is likely, in the first instance, to focus on a number of 


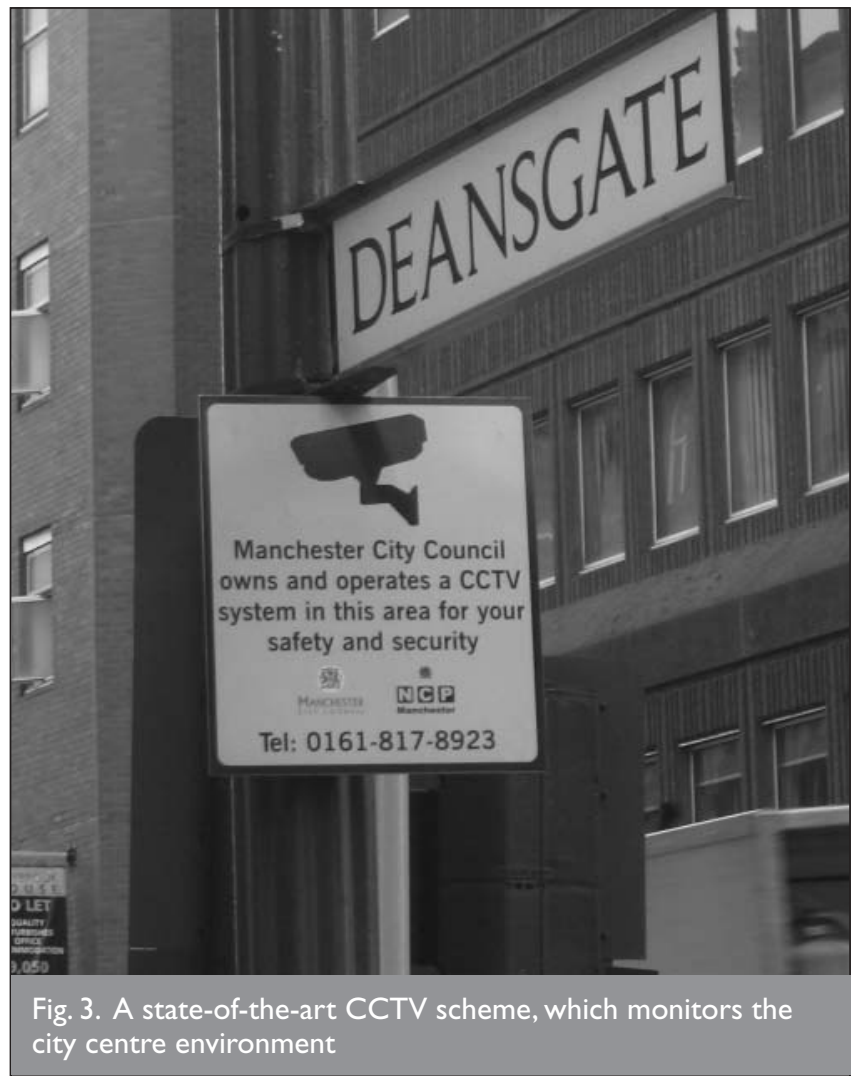

design instructions, using the principles listed above in a similar way to the US Department of Commerce's National Institute of Standards and Technology (NIST) guidance. NIST principles apply to the construction of public buildings where the goal is to develop a target hardened environment that will deter the would-be terrorist from attacking or mitigate the impact of an attack if one were to occur. Examples of what has been seen as 'must obey' design instructions include: setting the building back from the street; limiting the number of entrances; removing first floor windows; having no underground car parks; and barrier protection around the site. ${ }^{23}$

Such a full integration of viewpoints between those that design and those with responsibility for securing urban spaces has, however, a long way to go. This has been acknowledged in the UK by connected streams of research being undertaken by government departments and research councils. ${ }^{24}$ Since 2006 Nactso has produced a detailed Hostile Vehicle Mitigation guide and has been developing guidance for the owners and mangers of sports stadia, bars, pubs, clubs and shopping centres, advising them of measures they might take to mitigate the impacts of terrorism against crowded public spaces. ${ }^{25}$ These are spaces that are often viewed as the centrepieces of design-led urban regeneration. This work on defending the regenerated spaces of the city was reinforced by pronouncements from the UK security minister, Lord West, in November 2007 as part of a review of anti-terror plans. This review in particular focused on how the architect or urban designer might help 'design-out' the terrorist threat to public places and transport hubs such as rail stations and airports. ${ }^{26}$ These areas currently are often protected, if at all, in a crude manner utilising concrete blocks and temporary vehicle control barriers (TVCBs) (see Fig. 4).

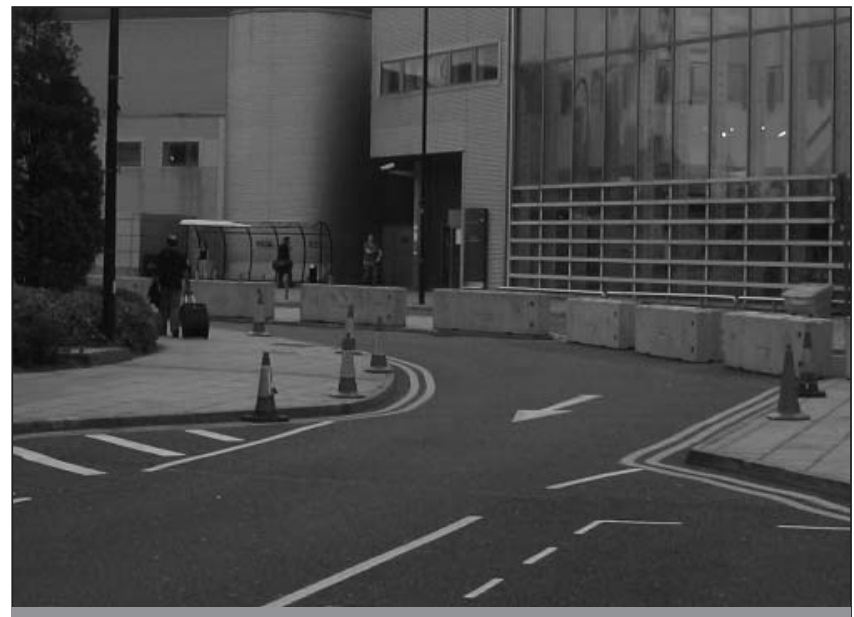

Fig. 4. Crude concrete barriers at Manchester airport, which were put in place after the attack against Glasgow airport in July 2007

Importantly in this review of anti-terror plans in the UK, emphasis was placed on security features being as 'unobtrusive' as possible and being built into design from the preconstruction phase. This draws on methods popularised in North America in the post 9/11 era of utilising softer, more subtle and 'landscaped' security-what has also been referred to as invisible security ${ }^{27}$-so that security features are designed into ornamental fences, sculptures, large flower planters, or where trees are used as a defensive cordon instead of highly visible security barriers (Jersey barriers). For example, security planning in Washington D.C. The National Capital Urban Design and Security Plan ${ }^{28}$ has six key goals, which are an active attempt to avoid 'fortress'-style security and to coordinate better the future development of security policy. The six key goals are as follows.

(a) Provide an appropriate balance between the need to accommodate perimeter security for sensitive buildings and their occupants and the need to maintain the vitality of the public realm.

(b) Provide security in the context of streetscape enhancement and public realm beautification, rather than as a separate or redundant system of components, the only purpose of which is security.

(c) Expand the palette of elements that can gracefully provide perimeter security in a manner that does not clutter the public realm, while avoiding the monotony of endless lines of jersey barriers or bollards, which only evoke defensiveness.

(d) Produce a coherent strategy for deploying specific families of streetscape and security elements in which priority is given to achieving aesthetic continuity along streets, rather than solutions selected solely by the needs of a particular building under the jurisdiction of one public agency.

(e) Provide perimeter security in a manner that does not impede the city's commerce and vitality, excessively restrict or impede operational use of sidewalks or pedestrian and vehicular mobility, or impact the health of existing trees.

(f) Identify an implementation strategy that can be efficiently coordinated in the most cost-effective manner. 
In the UK the importance of 'unobtrusive' security was exemplified in Lord West's (November 2007) report by the newly constructed Emirates football stadium in North London, which was held up as a model for designing-in counterterrorism to new buildings. For example the stadium is ringed by a variety of ornaments or streetscape designs, from reinforced benches to large brass cannons (Arsenal football club's insignia) and large 'toughened' concrete letters spelling out 'Arsenal', which are deliberately situated to prevent vehicle access and, according to reports, can stop a $7 \mathrm{t}$ lorry (see Fig. 5). ${ }^{29}$

At present, and despite a focus on more subtle security measures being designed-in to urban regeneration projects and schemes, there appear to be a number of long-standing disagreements among built environment professionals regarding the desire and practicalities of terror-proofing urban areas and embedding such resilience into the practices of urban regeneration.

First, there is the question of proportionality. Many urban professionals are sceptical about current guidance that is available to planners, architects and designers regarding the need to design-in counter-terrorism. This discussion often focuses around perception of threat (i.e. in the UK many see London as the only viable target) and long-standing concerns about creating a 'fortress' mentality and planning for the worst possible scenario. ${ }^{30}$ In short, many built environment professionals see it as unacceptable to take the sort of solutions being suggested by the government and are concerned about possible local government legislative changes that might 'force' such solutions to be adopted. For example, in the same month (November 2007) that the government in the UK reaffirmed its desire to design-in security to crowded public places, they also issued a wide-ranging consultation document regarding national indicators for local authorities and local authority partnerships. Buried within this vast document is National Indicator 36 (NI 36) under the broad banner of community safety but with particular reference to 'Protection against a terrorist attack'. NI 36 indicates that a local authority and its partners, in liaison with the local police and specialist counterterrorism security advisors, will have a statutory duty to ensure that the protection of crowded places is 'robust'. ${ }^{31}$

Second, there is the question of acceptability and cost. There are concerns about the impact on the general public of introducing the high-visibility security measures often emphasised by the government security advisors. For example, speculation about all mainline rail stations having to construct exterior security barriers and consider airport-style screening of passengers and their luggage is unlikely to be met with enthusiasm from the rail operators and the public owing to cost and the vast amount of time it would take to undertake such checks. Likewise, it is unlikely that many building owners and operators, or developers, will want to install or retrofit counterterrorist designs in areas of the county that do not appear to be at severe risk from terrorism.

Third, there is the question of aesthetics. Many recent commentators have argued that the forced adoption of counter-terrorist

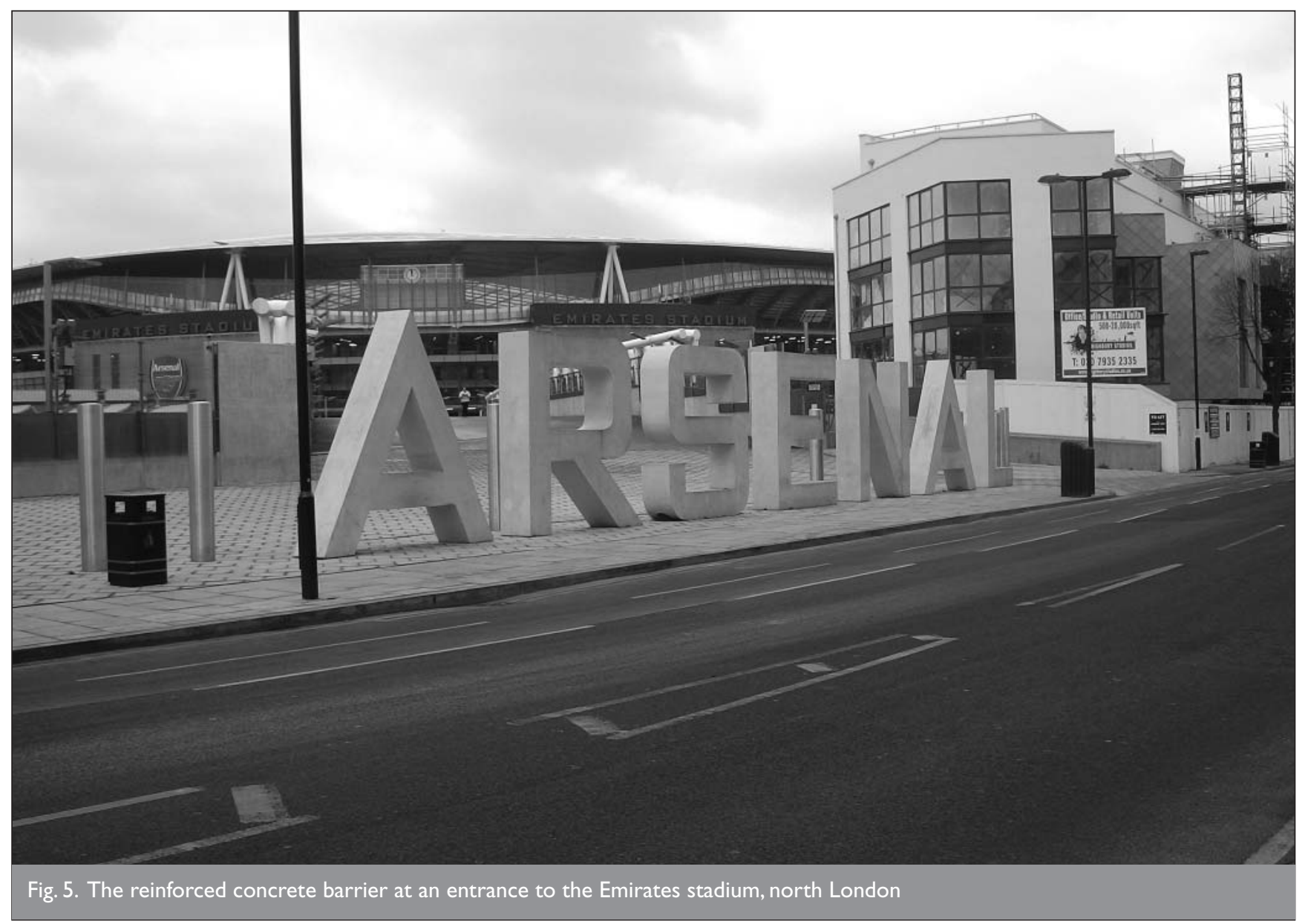


principles within design could lead to less visibly pleasing architecture and the increased control of access to public space, in direct contradistinction to the principles of a design-led urban renaissance. As Stephen Bayley points out in a recent newspaper article, however, security features (and implicitly other hazard mitigation measures) need to be acceptable from an aesthetic point of view 'We might live in dangerous times, but they don't have to be ugly ones too' ${ }^{32}$ Here finding the right balance between 'subtlety' and 'safety' is vital. ${ }^{33}$ This is not a new argument. Influential architectural critic Martin Pawley ${ }^{34}$ argued that as a result of an upsurge in urban terrorism, especially against "the highly serviced and vulnerable built environment of the modern world', the new wave of signature buildings could be replaced by an 'architecture of terror', as a result of security needs. This he argued could well have the function of making the buildings 'anonymous', and thus, he concluded, a less unattractive terrorist target. He further inferred that this 'architecture of terror' will be selfreproducing as planning guidelines once drawn up will be difficult to withdraw, and such defensive architecture will become 'impossible to resist' owing to calls to reduce the impact of terrorism through urban and architectural design. Recent calls by the government in the UK for architects (and by inference other built environment professionals) to take a lead on designing-out terror highlights how Pawley's prediction might slowly be coming true. Nonetheless it is important to bear in mind the differences between security features that might be designed-in but are meant to be as 'unobtrusive' or 'invisible' as possible, and those that are designed as an active and visible deterrent.

\section{SECURITY AND ENVIRONMENTAL \\ SUSTAINABILITY}

In recent decades environmental sustainability, like security, has become an increasing priority for planning, architectural and construction projects, as well as society at large, and the potential clash between these agendas was the driving force behind a recent symposium organised by the Public Entity Risk Institute in the USA. ${ }^{35}$ The present authors argue here that one way to ensure that security features are embedded in an acceptable and appropriate manner within planning and design is by integrating such considerations with ideas of sustainability and reduced energy consumption.

Although terrorism appears to be the main policy driver behind developing increasingly secure urban environments, the concern for environmental sustainability is likely in the future to be increasingly important in urban design. ${ }^{36}$ Cozens, for example, highlighted the possible complementarity between crime prevention and sustainability measures in what he terms the new age of 'sustainable urban environmentalism. ${ }^{37}$ In such a scenario there is now a need to think critically about building in 'resilience' to both the design and management of urban areas so as to better balance the competing concerns of creating an increasingly 'secure' and 'green' city.

These competing agendas are not as unconnected as they might first appear and opportunities exist to integrate or retrofit sustainable and secure ideas simultaneously in the built environment. As Paradis and Tran note 'on the surface, it may appear that secure/safe design has little relationship to sustainable design. Yet, security and safety measures, such as those for anti-terrorism must be considered within a total project context, including impacts on occupants and the environment, regardless of the level of protection deemed appropriate'. ${ }^{38}$

In the UK policy advances in countering crime and terrorism within the context of environmental sustainability and 'resilience' most notably includes the Sustainable and Secure buildings Act (2004). This act, along with a set of building regulations, has been developed to further the conservation of fuel and power, prevent waste, undue consumption, misuse or contamination of water, further the protection or enhancement of the environment, facilitate sustainable development and/or further the prevention or detection of crime or terrorism..$^{39}$ The Act also meant that for the first time the physical security of buildings was legislated for. To date, however, in practice there has been a far greater focus on the 'greening' of buildings than on embracing the requirements of security ${ }^{40}$ Rydin et al. have even suggested that the 'green' aspects of the Act and related guidance have been treated with a rather laissez faire attitude, in that a review of the government literature "could lead to the conclusion that sustainable construction is largely a matter for the construction industry itself to innovate and self-regulate, and for building inspectors to consider in enforcing building regulations'. ${ }^{41}$ It would be pertinent to suggest that similar conclusions could also be drawn for the 'secure' aspects of the Act and that in years to come the alteration of the built environment in response to risk (especially terrorism) is likely to come from a number of design and governance mechanisms that will also have implications for environmental sustainability and energy efficiency.

\section{I. Design alteration to balance security and sustainability}

What is required is a greater integration and balancing of sustainability and security as key underlying principles within the construction of the built environment. ${ }^{42}$ These goals can sometimes be in conflict, while at other times might work in synergy. The critical question remains how can these priority concerns be planned in a joined-up way? ${ }^{38}$ Practically speaking these could also become embedded within building and planning codes or guidance for sustainable construction. Once again US codes for federal facilities and public buildings are leading the way in exploring ideas of joining up energy conservation and security for practical reasons and, importantly, for cost savings. ${ }^{43}$

Although there are very few building designs that combine concerns with energy efficiency and security outside of federal or government buildings, examples of practical conflicts between security and sustainability might include, for example, increasing the glazing on a building for increased sunlight and hence reduced heating bills, although from a security perspective this increases the glass hazard in the event of an explosion (the need here is for laminated glass or the application of anti-shatter film) or the need for target hardening through protective building perimeters (stand-off areas), which will increase the concreting of open space and increase the urban heat island effect. Likewise enacting technological measures to increase building resilience might well increase electrical loads of buildings. 
Examples of synergies between security and sustainability might include developing landscaping systems that are both 'green' and can conform to crime prevention through environmental design principles, for example, ponds and strategically planted trees acting as physical barriers instead of expanses of concrete and rows of steel bollards. It is also possible that such ponds and landscaping features could be used as part of sustainable urban drainage systems (SudS) that are designed to reduce the occurrence and impact of flooding in urban areas. Integrating security systems with other built systems at the design stage (whole building design) can reduce energy use, as can the use of thick thermal walls or window film, which better insulates a building while providing additional blast resistant cover. Furthermore, developing what engineers refer to as a 'tight building envelope' can reduce the infiltration of cold air and retain thermal performance, as well as reducing the permeation of potentially harmful chemical, biological or radiological air-borne agents. Table 1 identifies a series of safe design strategies and how they might be integrated with sustainable design opportunities. ${ }^{38}$

In delivering an enhanced level of security, there are of course questions of cost to address, which are especially important in times of budgetary limitation. For example, retrofitting or retrospective solutions to existing urban landscapes and buildings will be far more costly than implementing them in new-build projects. In terms of economic efficiency, there is now a tremendous opportunity, especially for new-build projects, simultaneously to embed energy-efficient and security features into the built environment, which can "contribute to the larger goals of an economy less vulnerable to energy supply and infrastructure disruptions and to generate long-term energy cost savings that will in turn lower the net cost of essential security improvements'. ${ }^{43}$

Importance should be placed on identifying the barriers that restrict the opportunities to integrate security and energyefficient measures in the built environment. ${ }^{43}$ Here a particular concern is the often embedded 'cultures' of respective security and sustainability professionals, which may mitigate against joint working practices. ${ }^{43}$

In the future a more inclusive and joined-up approach to integrating security and environmental sustainability should be advanced through the greater collaboration between a wide range of stakeholders-architects, engineers, planners, the police, insurers, surveyors and so on, and, importantly, the public-who are, or should be, involved with the planning, design, construction, operation and management of the built environment. ${ }^{44}$

\section{ACKNOWLEDGEMENT}

The research for this paper has been supported in part by an Engineering and Physical Sciences Research Council grant (EP/ F008635/1).
Access control

Secure site perimeter and use barriers to prevent passage of vehicles

Install electronic access systems (e.g. parking, elevators)

\section{Surveillance}

Place windows and doors to allow for good visibility and avoid spaces that permit concealment

Design lighting to reinforce natural surveillance and install intrusion devices and video systems and use screen and tracking systems

Blast protection

Use building configurations for improved resistance to blast shock waves

Maximise distances between parking and buildings

Size and locate windows with detonation points in mind

Use blast- or ballistic-resistant glazing and increase strength of exterior cladding and non-structural elements

Chemical, biological, radiological protection

Elevate fresh air intakes

Reduce need for utilities

Apply external air filtration and use internal air filtration technologies

Secure vulnerable areas (e.g. mail rooms, loading docks, storage)
Integrate with sustainable landscaping scheme. Use natural and/or environmentally friendly barriers (e.g. trees, retention ponds, recycled-content planters, etc.)

Use energy-efficient systems. Consider renewable and/or distributed energy resources

Integrate with daylighting scheme

Integrate with building automation and control systems. Use energy-efficient systems. Consider renewable and/or distributed energy sources, such as solar power night lighting

Integrate with passive solar design and daylighting scheme

Integrate with alternative transportation plans

Integrate with daylighting scheme

Use blast- or ballistic-resistant and energy-efficient window films.

Use sustainable materials. Consider thermal benefits of strengthened cladding options

Consider dedicated ventilation and/or exhaust systems Integrate with energy-efficient systems

Consider renewable and/or distributed energy resources

Integrate with building automation and control systems

Consider dedicated ventilation and/or exhaust systems

Table I. Integrating strategies for safety, security and sustainability 


\section{REFERENCES}

1. Tierney K. and Bruneau M. Conceptualizing and measuring resistance: a key to disaster loss reduction. TR News, 2007, 250, May-June, 14-17.

2. Pelling M. The Vulnerability of Cities: Natural Disaster and Social Resilience. Earthscan, London, 2003.

3. Hamelin J. P. and Hauke B. Focus Areas: Quality of Life-Towards a Sustainable Built Environment. European Construction Technology Platform, Paris, 2005.

4. Bosher L. S. Introduction: The need for built-in resilience. In Hazards and the Built Environment: Attaining Built-in Resilience (Bosher L. S. (ed.)). Taylor and Francis, London, 2008.

5. Branscomb L. Sustainable cities: safety and security. Technology in Society, 2004, 28, 225-234. COAFFEE J. Terrorism, Risk and the City. Ashgate, Aldershot, 2003.

6. DAinty A. R. J. and Bosher L. S. Afterword: Integrating resilience into construction practice. In Hazards and the Built Environment: Attaining Built-in Resilience (BosHER L. S. (ed.)). Taylor and Francis, London, 2008.

7. URban TASK Force. Towards a Strong Urban Renaissance. 2005. See www.urbantaskforce.org for further details.

8. GodschalK D. R. Urban hazard mitigation: creating resilient cities. Natural Hazards Review, 2003, 4, No. 3, 142.

9. Litrle R. Holistic strategy for urban security. Journal of Infrastructure Systems, 10, No. 2, 55.

10. Rogers P. and CoAfFeE J. Moral panics and urban renaissance: policy, tactics and lived experiences in public space. City, 2005, 9, No. 3, 321-340.

11. Murakami Wood D. and Coaffee J. Lockdown! Resilience, resurgence and the stage-set city. In Securing the Urban Renaissance (Atkinson R. and Helms G. (eds)), Policy Press, Bristol, 2007, pp. 91-106.

12. Roaf S., Crichton D. and Nicol F. Adapting Buildings and Cities for Climate Change. Architectural Press and Elsevier Press, London, 2005.

13. McEvoy D., Lindley S. and Handley J. Adaptation and mitigation in urban areas: synergies and conflicts.

Proceedings of the Institution of Civil Engineers, Municipal Engineer, Special Issue: Climate Change, 2006, 159, No. 4, 185-191.

14. American Planning Association. Safe Growth America Checklist. American Planning Association, 2004. See http:// www.planning.org/katrina/pdf\%5CSafeGrowthAmericaChec klist.pdf for further details.

15. American Planning Association. What Is Safe Growth America? American Planning Association, 2005. See http://www.planning.org/features/2005/whatissafegrowth. $\mathrm{htm}$ for further details.

16. Bosher L. S., Carrillo P. M., Dainty A. R. J., Glass J. and Price A. D. F. Realising a resilient and sustainable built environment: Towards a strategic agenda for the United Kingdom. Disasters: The Journal of Disaster Studies, Policy Et Management, 2007, 31, No. 3, 236-255.

17. Office of the Deputy Prime Minister. Safer Places : The Planning System and Crime Prevention. ODPM/Home Office, London, 2004.

18. CoAffee J. Terrorism, Risk and the City. Ashgate, Aldershot, UK, 2003.

19. CoAffee J. and Rogers P. Rebordering the city for new Security challenges: from counter-terrorism to community resilience. Space and Polity, 2008, 12, No. 1, pp. 101-118.
20. Davey C., Wootton A. and Hodge M. Designing against terrorism. Engineering Design, 2005, January/February, 10-13.

21. See http://www.arup.com/securityconsulting/feature. cfm?pageid=4642 for further details (accessed 01/03/2008).

22. National Counter Terrorism Security Office. Crowded Places Business Questionnaire. NaCTSO, London, 2007.

23. Regan M. Blast proof city. In Planning in London Yearbook, Excel Publishing, Manchester 2006, pp. 22-24.

24. See http://www.manchestereveningnews.co.uk/news/ s/1024659_designer_war_on_terror?rss=yes?rss=yes for further details (accessed 01/03/2008).

25. See http://www.nactso.gov.uk/ for further details.

26. Travis, A and Wintour, P. Rail passenger face anti-terror searches, The Guardian, 2007, Thursday $15^{\text {th }}$ November, 4.

27. BRIgGs R. Joining Forces: From National Security to Networked Security. Demos, London, 2005.

28. National Capital Planning Commission. The National Capital Urban Design and Security Plan. National Capital Planning Commission, Washington D.C., 2002, p. 2.

29. How to Terror-proof Shopping Centres and Other Buildings. See http://news.bbc.co.uk/1/hi/magazine/7095884.stm for further details, 15 November 2007 (accessed 01/03/2008).

30. Ancell H. Government calls for anti-terror design. Building Design Online. See http://www.bdonline.co.uk/story. asp? storyCode $=3100087$ for further details, 14 November 2007 (accessed 01/03/2008).

31. Department for Communities and Local Government. National Indicators for Local Authorities and Local Authority Partnerships: Handbook of Definitions, Draft for Consultation. Department for Communities and Local Government, London, November 2007.

32. Bayley S. From car bombs to carbuncles. The Observer, 18 November 2007. See http://observer.guardian.co.uk/review/ story/0,,2212697,00.html for further details.

33. See http://www.designbuild-network.com/features/ feature507/ for further details (accessed 01/03/2008).

34. PaWley M. Terminal Architecture. Reaktion, London, 1998, p. 148.

35. Infrastructure risk and renewal: The clash of blue and green. Proceedings of the PERI Symposium. See http:// www.riskinstitute.org/PERI/SYMPOSIUM/ for further details (accessed 01/03/2008).

36. Du Plessis C. The links between crime prevention and sustainable development. Open House International, 1999, 24, No. 1, 33-40.

37. Conzens P. Sustainable urban development and crime prevention through environmental design for the British city: Towards an effective urban environmentalism for the 21st century. Cities, 2002, 19, No. 2, 135.

38. Paradis R and Tran B. Whole Building Design Guide: Balancing Security/Safety and Sustainability Objectives. National Institute of Building Sciences, Washington, 2007. See http://www.wbdg.org/design/balancing_objectives.php for further details.

39. Her Majesty's Stationery Office. Sustainable and Secure Buildings Act 2004. HMSO, London, Ch. 22.1.

40. Dance S. Construction time again. Security Management Today, 2005, 1, 5 March. See http://www.info4security. com/story.asp? sectioncode $=10$ etstorycode $=3057545$ for further details (accessed 01/03/2008). 
41. Rydin Y., Amjad U., Moore S., Nye M. and Whitaker M. Sustainable Construction and Planning: The Academic Report. Centre for Environmental Policy and Governance, London School of Economics, London, July 2006.

42. Oberle R., Pohlman T. and Roper K. A model for balancing sustainability versus security. Computer Aided Optimum Design in Engineering IX: Transactions in the Built Environment, 2005, 80, 383-391.
43. HARris J., Tschudi W. and Dyer B. Securing Buildings and Saving Energy: Opportunities in the Federal Sector. US Department of Energy Federal Energy Management Program, 2002. See http://www.dc.lbl.gov/ harris/ Downloads/Securing\%20Buildings $\% 20$ and $\% 20$ Saving $\% 20 \mathrm{E}$ nergy.pdf for further details.

44. Bosher L. S., Dainty A. R. J., Carrillo P. M., Glass J. and PRICE A. D. F. Integrating disaster risk management into construction: A UK perspective. Building Research and Information, 2007, 35, No. 2, 163-177.

\section{What do you think?}

To comment on this paper, please email up to 500 words to the editor at journals@ice.org.uk. Your article will be considered for publication in the journal. The original author(s) will also be invited to respond.

Proceedings journals rely entirely on contributions sent in by urban designers, planners, civil engineers and related professionals, academics and students. Papers should be 2000-5000 words long, with adequate illustrations and references. Please visit www.thomastelford. com/journals for author guidelines and further details. 